\title{
Balanced scorecard and performance in a competitive environment
}

\author{
Rihab Guidara *, Walid Khoufi \\ Department of Finance and Accounting, Faculty of Economics and Management, University of Sfax, Tunisia \\ *Corresponding author E-mail: rihabguidara@hotmail.fr
}

\begin{abstract}
This paper reports the results of an empirical investigation into strategic performance measurement systems. More specifically, it examines how the Balanced Scorecard (BSC) is associated with the intensity of market competition and the organizational performance. To test these associations, data were collected from 50 Tunisian agribusiness units. The results indicate that the intensity of market competition is a determinant of the use of the BSC which, in turn, is a determinant of organizational performance.
\end{abstract}

Keywords: Market Competition, BSC, Organizational Performance.

\section{Introduction}

New management approaches necessitate measuring the products quality, the employees' competence (Fullerton et al., 2002) and strategic resources and key success factors (Kaplan and Norton, 1996; Hoque et al., 2001). So, it is therefore imperative to redirect the performance measure on the strategic dimensions and the long term (Bromwich, 1990; Davis et al., 2004; Abdelmaksoud et al., 2005; Papalexandris et al., 2005; Chenhall, 1998b; Michalska, 2005; Ward, 1993; Kaplan and Norton, 1996; Sohn et al., 2003).

The adjustment of performance measurement with the multidimensional reality of the business corrects myopic financial measures and promotes the emergence of a strategic performance measurement approach. This approach includes, in addition to financial information, non-financial items that are part of the overall company's strategy (Chenhall, 2003; Sohn et al., 2003, Mia et al., 1999, Miller et al., 1993).

These performance system measures align performance measures with strategy and business objectives (Kaplan and Norton, 1996; Ukko, 2007; Chenhall, 2005; Ittner et al., 2003; Braam, 2004), enable managers to control and enhance their skills (Widener, 2006; Chenhall, 2005; Kald et al., 2000; Martinez, 2005; Lau et al., 2005), translate the business strategy into action (Chenhall, 2005; Martinez, 2005), and ameliorate decision making, product quality and customer satisfaction (Ukko et al., 2007). So, they improve the group performance (Scott et al., 1999, Kald et al., 2000), the managers' satisfaction (Ittner et al., 2003, Lau et al., 2005), the financial results (Ittner et al., 2003; Davis et al., 2004) and the overall performance of the company (Braam, 2004; Chenhall, 2005; Mahama, 2006; Widener, 2006; Ukko, 2007).

In this context, Robert Kaplan and David Norton created at the begging of 1990s, a theoretical valuation model, called Balanced Scorecard (BSC). This model allows a control system based on the external environment and translates business strategy in terms of performance.

To enrich the research on the improvement of control, we empirically examine the relationship between the competitive environment, the BSC and the performance. The paper is structured as follows: first, the theoretical constructs underpinning the research are outlined; the research methods are then described followed by the results.

\section{Literature and hypotheses}

\subsection{The balanced scorecard concept}

Firms have traditionally been evaluated using traditional financial information. This type of information is the most reliable (Cardot, 1980) and provides investors and managers with a common denominator for the financial calculation and measurement of performance (Emmanuel, 1990). However, it's too aggregated, incomplete and insufficient (Hopwood, 1972; Yaich, 2004; Bryer, 2006), it can provide misleading signals and can be sufficient only in a stable environment (Otley, 2001). In a dynamic environment, some alternative measurements have been recommended based on non-financial performance in order to measure the organizational performance (Kaplan and Norton, 1992; Van Veen-Dinks, 2002).

To remedy the deficiency of traditional financial information, Kaplan and Norton (1992) propose a multidimensional performance indicator called Balanced Scorecard. The BSC has involved, from the performance measurement tool (Kaplan and Norton,1992), to a tool for implementing strategies (Kaplan and Norton, 1996) and a framework for determining the alignment of an organization's human, information and organization capital with its strategy (Kaplan and Norton, 2004a). The BSC is balanced because it fosters a balance between short- and long-term objectives, between desired outcomes (lag performance measures) and the performance drivers of these outcomes (lead performance measures), between quantitative-objective measures and qualitative-subjective measures, between financial and non-financial measures, and between external and internal perspectives of performance. For a given period, the BSC lists the objectives sorted into four categories:

Financial perspective: applying appropriate financial performance measures to ascertain whether the company is profitable. 
Customer perspective: assessing customer satisfaction. In a competitive market, customers must be content, or market share will drop. Customers care about price, faster and reliable deliveries, design, quality and level of services.

Internal business (Processes) perspective: tracking interorganizational indicators to determine whether the business units are efficiently using resources and ascertaining competitive performance in developing 'next generation' products.

-Learning and growth (Organizational Development) perspective: this dimension measures such things as training and development, information systems, employee satisfaction, employee productivity, etc.

These 4 perspectives are linked to each other by cause and effect architecture establishing a relationship between the objectives "performance outcome" and the means used to achieve the expected results "performance drivers". So, the competent employees improve the design of internal processes, which in turn improves customer satisfaction and subsequently shareholder satisfaction increases. The Balanced Scorecard (BSC) aims at providing "a framework that translates strategy into action" Kaplan and Norton (1996). It derives consequently strategic goals into operating goals and actions. This procedure is used to describe, implement, review and control the strategy in all levels of the company, by linking in a logical way objectives, initiatives and indicators to long term change. It allows non-financial measures "lead indicators" to control the financial measures "lag indicators" and predict future financial performance (Kaplan and Norton, 1996). This approach aligns with the company's strategy, and in deriving the objectives and measures of business units strategic business processes (Kaplan and Norton, 1996). The BSC controls the company at three levels: profits, management and equilibrium between the short and the long term (Otley, 2003). The BSC is according to Papalexandris and al. (2005) "a model that let performance transparent for the entire company."

\subsection{Market competition and BSC}

In competitive environment, product's value includes functionality, quality, distribution, after-sales services, and speed of change, price and flexibility to customer requirements (Chenhall, 2005). To be competitive, firms have to control their costs and delays, differentiate their products, improve quality, reduce their life cycle and respect new environmental requirements (Fullerton and al, 2002; Michalska, 2005). Organizations facing higher competition are likely to make greater use of multiple measures than just traditional performance measures. The financial information is historical and narrow in focus reflecting only the financial perspective of the company and ignoring other key success factors (Norreklit, 2000; Otley, 2001). Hoque (2003) suggests that traditional accounting analyzes production costs but not the quality. It can't report effects of intangible assets on wealth creation (Waterhouse, 1999). It's also limited to the short term and cant' predict (Norreklit, 2000; Azofara et al., 2003; Hoque, 2003). In addition, it does not link the performance objectives of the company and does not disclose how to develop the key success factors (Kaplan and Norton, 1993).

New concepts of quality, flexibility and reliability require new management accounting systems capable of providing better information for managerial decision making (Gordon et al., 1984; Joseph et al., 1996; Burns et al., 2000; Mia et al., 1999; Lipe et al., 2002; Bititci, 2005). The company based on new management approaches need to quantify the quality of its products and the competence of its employees (Fullerton et al., 2002), its operations and relevant areas of business (Hoque et al., 2001) and its strategic resources and key success factors (Kaplan and Norton, 1996).

Some empirical studies provide evidence to support the relationship between changing business environment and changing performance measures. For example, Gordon et al. (1984) showed that American companies facing higher competition are likely to use multiple performance measures: external information, nonfinancial information and ex-ante information in the decision- making process. The study of Mia and Clarke (2005) carried out on 71 New Zealand-based manufacturing units suggests that greater emphasis on multiple measures for performance evaluation is associated with businesses facing high competition. Abdelmaksoud et al. (2005) suggest that in a highly competitive economic environment the British industrial companies opt for measures that reflect all organizational dimensions (customer satisfaction, product quality, timely delivery, efficiency and morality employees). Other empirical studies have confirmed the relationship between changing business environment and the use of the BSC as a multidimensional performance measurement system. For example, Sohn et al. (2003) suggest that the adoption of the BSC in Korea is a response to the dynamism and heterogeneity as well as the hostility of the environment. Hoque et al. (2001) suggest that in the New Zealand industrial companies, modern manager have to use the BSC to control environmental factors and achieve a sustainable competitive advantage.

Following the above discussion we argue that as market competition intensifies, managers make a greater use of the BSC. We formulate this hypothesis as follow:

H1. There is a positive and significant relationship between market competition and managers' use of the BSC measurement.

This hypothesis is structured in 4 partial hypotheses:

H1.a. There is a positive and significant relationship between market competition and managers' use of financial measurement.

H1.b. There is a positive and significant relationship between market competition and managers' use of customer measurement.

H1.c. There is a positive and significant relationship between market competition and managers' use of internal business measurement.

H1.d. There is a positive and significant relationship between market competition and managers' use of learning and growth measurement.

\subsection{BSC and performance}

A few empirical studies refute the strategic performance measurements' efficiency in modern firms. This is due in particular to the existence of difficulties and barriers to their implementation (Tuomela, 2005; Braam et al., 2004) and the complexity and instability of the variables (Dilla et al., 2005; Tuomela, 2005; Sohn et al., 2003). Other authors attack especially the BSC because of the weakness of its theoretical concept (Bessire et al., 2005; Norreklit, 2000; Norreklit, 2003).

However, the most empirical studies suggest a positive relationship between strategic performance measurement systems and the performance of company. Ittner et al. (2003) suggest that the use of a set of diversified measures of performance improve the managers' satisfaction and market returns. Mahama (2006) suggests a positive effect (direct and indirect -through cooperation-) of performance measurement systems on performance, in Australian firms. Widener (2006) also showed a positive effect of multidimensional measurement systems on financial performance, in the American context.

Other authors studied the effect of using BSC as a performance system measure on the performance of the company. For example, Braam et al. (2004) show that the use of a BSC in harmony with companies' policy improves the performance of Dutch companies. Davis et al. (2004) show that the BSC has a positive effect on financial performance at bank branches. Chenhall (2005) suggests that Australian industrial companies use the BSC as a strategic management tool providing to managers full feedback which motivates managers and turns into performance. The exploratory qualitative study of Ukko et al. (2007) conducted in Finland show that the use of BSC improves the interaction between management and employees and increases business' performance.

Following the above discussion we argue that as managers make a greater use of the BSC, companies make a greater performance. We formulate this hypothesis as follow:

$\mathrm{H} 2$. There is a positive and significant relationship between managers' use of the BSC measurement and performance. 
This hypothesis is structured in 4 partial hypotheses:

H2.a. There is a positive and significant relationship between managers' use of financial measurement and performance.

H2.b. There is a positive and significant relationship between managers' use of customer measurement and performance.

H2.c. There is a positive and significant relationship between managers' use of internal business measurement and performance. H2.d. There is a positive and significant relationship between managers' use of learning and growth measurement and performance.

In addition to our two direct hypothesis ( $\mathrm{H} 1$ and $\mathrm{H} 2$ ), we add a third hypothesis (H3) testing the indirect effect of market competition on performance to show the mediating effect of the BSC in this relation. We formulate this hypothesis as follow:

H3. There is a positive indirect relation between market competition and performance through the use of the BSC.

\section{Research method}

\subsection{The sample}

Data were collected from 50 agro-food Tunisian firms. This choice is motivated by the fact that this sector is the most representative of the Tunisian economy and involved in the international environment (API, 2007 APIE, 2007). Using questionnaire survey on a 5-point Likert scale, a sample of 90 firms was invited to participate in the study. The list of firms was selected from the APIs' site web. The pilot test conducted with 3 firms revealed some adjustment of terms. These are the chief executive officers (CEO), the accountants and the management accountants, who are requested to respond to the questionnaire. Only 50 questionnaires were fully completed and returned, yielding a response rate of $55 \%$.

\subsection{Measurement of variables}

\subsubsection{Intensity of market competition}

Sohn et al. (2003), inspired by Miller's (1987) and Teo and King's (1997) studies considered three factors: dynamism, heterogeneity, and the hostility of the environment. Abdel-Maksoud et al. (2005) considered quality, innovation, customer service, price, delivery and flexibility. The most used measures in the literature result from the Khandwallas' method (1972). Khandwallas' method provides a rich valuation for recent research reference (Hoque et al., 2001; Chong et al., 2004). Khandwalla (1972) considered price product and marketing or distribution channel as factors comprising the market competition. Other studies (e.g. Gordon and Naryanan, 1984; Mia et al., 1999) have extended the Khandwalla's (1972) model by incorporating other competition factors such as new entrants in the market, competitors' strategies and actions, number of competitors, and regulations.

Following Chong et al. (2004), based on Khandwalla's (1972) and Mia et al.'s (1999) measures, our study conceptualizes the intensity of market competition consisting of 10 factors : 1)number of competitors in the market, 2) technological progress 3) new product development, 4)price, 5)client services, 6)product differentiation, 7) flexibility in responding to client demand, 8) marketing or distribution channels, 9) raw material availability, 10) regulations change. Respondents were asked to indicate, on a five-point Likert-type scale ranging from one (very low competition) to five (very high competition), the intensity of their business unit's market competition with respect to the above competition factors.

The analysis of items indicates that KMO test (Kaiser Meyer and Olkin) is judged commendable (0.876) and Bartlett's test of sphericity is significant and indicates a rejection of the hypothesis of equality of inter-relationship. A factor analysis of the scores for the items extracted a single factor with eigenvalue greater than unity, suggesting that the measure is unidimentional. The factor accounted for $64.951 \%$ of the variance. The Cronbach alpha for the measure in the study was 0,9378 indicating a satisfactory internal consistency and reliability of the measure.

\subsubsection{Business performance}

Subjective measures of performance could include manager satisfaction (Ittner et al., 2003), client satisfaction (Gainey and Klaas ,2003), comparison of firm's results with those of competitors (Miller et al., 1992; Chenhall, 2005; Robinson et al., 1988; Van de Ven and Ferry, 1980) and comparison of firm's results with its objectives (Mia et al., 1999). According to Mia et al. (1999) "A major advantage of multidimensional performance measure system as compared to ROI (Return On Investment) is that it includes every aspect of the performance : quantitative and qualitative, financial and non-financial". We have also drawn on the measures employed by Chenhall (2005) (competitive pricing and production flexibility) and Chong et al. (2004) (production volume, level of innovations created, and employee attitudes).

Our study conceptualizes the business performance consisting of 12 factors : 1) return 2) production cost 3)competitive pricing, 4)profit, 5)production volume, 6) sale volume 7) market share, 8) product quality, 9)production flexibility, 10) services quality 11) level of innovations created, 12) employee attitudes. Respondents were asked to indicate, on a five-point Likert-type scale ranging from one (not at all realized) to five (perfectly realized).

The analysis of items indicates that KMO test (Kaiser Meyer and Olkin) is judged wonderful (0.93) and Bartlett's test of sphericity is significant and indicates a rejection of the hypothesis of equality of inter-relationship. A factor analysis of the scores for the items extracted a single factor with eigenvalue greater than unity, suggesting that the measure is unidimentional. The factor accounted for $69.062 \%$ of the variance. The Cronbach alpha for the measure in the study was 0,9584 indicating a satisfactory internal consistency and reliability of the measure.

\subsubsection{The BSC}

Kaplan and Norton (1996) suggest that multiple performance measures reflect the organization's changing business environment as well as the achievement of its goal. After the listing of a given objective, the BSC lists the measures for that objective. For each measure, the BSC lists the correlative initiative taken, the target level, and the actual level of the measure for the period. The original BSC (1992) contains 3 items in the financial perspective and 17 items scattered over the others perspectives (Hoque et al., 2001; Lau and al, 2005). Sohn et al., (2003) keep the same perspectives of the original BSC but modify the items. Davis et al., (2004) use specific BSC employed by a particular company Papalexandris (2005) uses the new version of BSC (2004). Our study uses the 4 perspectives of the original model of Kaplan and Norton (1992), not only because of its popularity but also for its success. Each perspective for the BSC is first analyzed as a variable and then as an item of the variable BSC.

The analysis of items indicates that KMO test (Kaiser Meyer and Olkin) is judged praiseworthy for financial perspective $(0,842)$, customer perspective $(0,862)$, internal business $(0,869)$ and Learning and growth $(0,883)$ and Bartlett's test of sphericity is significant and indicates a rejection of the hypothesis of equality of interrelationship. A factor analysis of the scores for the items extracted a single factor with eigenvalue greater than unity, suggesting that the measure is unidimentional. The Cronbach alpha for the 4 measures in the study $(0.9273,0.9081,0.914$ and 0.9462$)$ was indicating a satisfactory internal consistency and reliability of the measure.

The analysis of the variable BSC represented by the 4 axis indicates that KMO test is passable $(0,700)$ and Bartlett's test of sphericity is significant. A factor analysis of the scores for the items extracted a single factor with eigenvalue greater than unity, suggesting that the measure is unidimentional. The factor accounted for $54.386 \%$ of the variance. The Cronbach alpha for the measure in the study was 0,7159 indicating a satisfactory internal consistency and reliability of the measure. 
Firm's size is added to the model to control for the possibility that business performance and performance measures usage may vary with business unit size and to reduce the problem of heterogeneity. Sales revenues, assets values and staff working can be proxies for business unit size. We measure the number of staff working by 5 intervals (less than 25 employees [25, 50 [, [50, 100 [, [100, 200 [, and more than 200 employees).

\section{Results}

\subsection{Market competition and BSC}

To test the effect of the intensity of market competition on BSC usage (H1) and on the 4 BSCs' perspectives, the following multiple regressions was run:

$$
\begin{aligned}
& B S C=B 0+B 1 C O N C U+B 2 \text { SIZE }+\epsilon \\
& \text { FINAN }=B 0+B 1 C O N C U+B 2 \text { SIZE }+\epsilon \\
& \text { CLIEN }=B 0+B 1 C O N C U+B 2 \text { SIZE }+\epsilon \\
& \text { PROCESS }=B 0+B 1 C O N C U+B 2 S I Z E+\epsilon \\
& \text { INNOV }=B 0+B 1 \text { CONCU }+B 2 \text { SIZE }+\epsilon
\end{aligned}
$$

Where;

$\mathrm{BSC}=$ balanced scorecard, $\mathrm{CONCU}=$ market competition, $\mathrm{SIZE}=$ firm's size, FINAN = financial perspective, CLIEN = customer perspective, PROCES = internal business perspective, $\mathrm{INNOV}=$ learning and growth perspective, $\beta 0=$ constant, $\beta=$ coefficient regression $-1<\beta<+1, \varepsilon=$ error term.

Table 1 indicates the presence of positive and significative relation between market competition and the use of BSC $(\beta=0,474$; $p=$ $0,001)$ and between market competition and measures of customer perspective $(\beta=0,627 ; p=0,000)$, internal business perspective $(\beta$ $=0,298, \mathrm{p}=0,038)$ and learning and growth perspective $(\beta=$ $0,342, p=0,015)$. But the relation between market competition and measures of financial perspective appears not to be signifi-

\begin{tabular}{|c|c|c|c|c|c|}
\hline variables & BSC & FINAN & CLIEN & PROCESS & INNOV \\
\hline constant & $\begin{array}{l}0,170^{\mathrm{ns}} \\
(0,575)\end{array}$ & $\begin{array}{l}0,201^{\mathrm{ns}} \\
(0,291)\end{array}$ & $\begin{array}{l}0,151^{\mathrm{ns}} \\
(0,332)\end{array}$ & $\begin{array}{l}0,186^{\mathrm{ns}} \\
(0,700)\end{array}$ & $\begin{array}{l}-0,148^{\mathrm{ns}} \\
(0,415)\end{array}$ \\
\hline $\mathrm{CONCU}$ & $\begin{array}{l}0,474^{* * * *} \\
(0,001)\end{array}$ & $\begin{array}{l}0,140^{\mathrm{ns}} \\
0,328\end{array}$ & $\begin{array}{l}0,627^{* * *} \\
(0,000)\end{array}$ & $\begin{array}{l}0,298^{* * *} \\
(0,038)\end{array}$ & $\begin{array}{l}0,342^{* *} \\
(0,015)\end{array}$ \\
\hline SIZE & $\begin{array}{l}0,106^{\mathrm{ns}} \\
(0,409)\end{array}$ & $\begin{array}{l}0,223^{\text {ns }} \\
(0,122)\end{array}$ & $\begin{array}{c}-0,167^{\mathrm{ns}} \\
(0,155)\end{array}$ & $\begin{array}{c}0,080^{\mathrm{ns}} \\
(0,570)\end{array}$ & $\begin{array}{c}0,164^{\mathrm{ns}} \\
(0,231)\end{array}$ \\
\hline $\begin{array}{l}\mathrm{R}^{2} \\
\text { adjusted }^{2}\end{array}$ & $\begin{array}{l}0,251 \\
0,220\end{array}$ & $\begin{array}{l}0,079 \\
0,040\end{array}$ & $\begin{array}{l}0,389 \\
0,363\end{array}$ & $\begin{array}{c}0,102 \\
0,064\end{array}$ & $\begin{array}{l}0,161 \\
0,125\end{array}$ \\
\hline J & $\begin{array}{l}7,891^{* * *} \\
(0,001)\end{array}$ & $\begin{array}{c}2,01^{\mathrm{ns}} \\
(0,145)\end{array}$ & $\begin{array}{l}14,981^{* * *} \\
(0,000)\end{array}$ & $\begin{array}{l}2,681^{*} \\
(0,079)\end{array}$ & $\begin{array}{l}4,496^{* *} \\
(0,016)\end{array}$ \\
\hline
\end{tabular}
cantly. These results support H1, H1.b; H1.c and H1.d. Business unit size appears not to be significantly associated with performance measures usage.

Table 1: Test of Hypothesis H1; H1.A; H1.B; H1.C and H1.D

\subsection{BSC and business performance}

To test the effect of the BSC usage on business performance (H2), and the effect of each BSCs' perspective on the business performance, the following multiple regressions was run:

$$
\begin{aligned}
& \text { PERFO }=B 0+B 1 \text { BSC }+B 2 \text { SIZE }+\epsilon \\
& \text { PERFO }=B 0+B 1 \text { FINAN }+B 2 \text { SIZE }+\epsilon \\
& \text { PERFO }=B 0+B 1 \text { CLIEN }+B 2 \text { SIZE }+\epsilon \\
& \text { PERFO }=B 0+B 1 \text { PROCES+B2 SIZE }+\epsilon \\
& \text { PERFO }=B 0+B 1 \text { INNOV+B2 SIZE }+\epsilon \\
& \text { Where; }
\end{aligned}
$$

\section{Where;}

PERFO $=$ business performance, $\mathrm{BSC}=$ balanced scorecard, FINAN $=$ financial perspective, CLIEN $=$ customer perspective PROCES $=$ internal business perspective, INNOV = learning and growth perspective, SIZE $=$ firms' size, $\beta 0=$ constant; $\beta=$ coeffi-

\begin{tabular}{|c|c|c|c|c|c|}
\hline Variables & BSC & FIN & $\begin{array}{l}\text { PERFO } \\
\text { CLIEN }\end{array}$ & PROCES & INNOV \\
\hline \multirow{2}{*}{$\begin{array}{l}\text { Constant } \\
\beta\end{array}$} & $\begin{array}{l}0,086^{\mathrm{ns}} \\
(0,646)\end{array}$ & $\begin{array}{l}0,160^{\mathrm{ns}} \\
(0,728)\end{array}$ & $\begin{array}{l}-0,224^{\mathrm{ns}} \\
(0,131)\end{array}$ & $\begin{array}{l}-0,112^{\mathrm{ns}} \\
(0,454)\end{array}$ & $\begin{array}{l}0,122^{\mathrm{ns}} \\
(0,800)\end{array}$ \\
\hline & $\begin{array}{l}0,891^{\text {*** }} \\
(0,000)\end{array}$ & $\begin{array}{l}0,574^{* * *} \\
(0,000)\end{array}$ & $\begin{array}{l}0,637^{* * *} \\
(0,000)\end{array}$ & $\begin{array}{l}0,627^{* * *} \\
(0,000)\end{array}$ & $\begin{array}{l}0,779^{* * *} \\
(0,000)\end{array}$ \\
\hline SIZE & $\begin{array}{l}0,044^{\mathrm{ns}} \\
(0,499)\end{array}$ & $\begin{array}{l}0,062^{\mathrm{ns}} \\
(0,612)\end{array}$ & $\begin{array}{l}0,249^{\mathrm{ns}} \\
(0,127)\end{array}$ & $\begin{array}{l}0,124^{\mathrm{ns}} \\
(0,271)\end{array}$ & $\begin{array}{l}0,034^{\mathrm{ns}} \\
(0,710)\end{array}$ \\
\hline $\begin{array}{l}\mathrm{R}^{2} \\
\text { adjusted } \\
\mathrm{R}^{2}\end{array}$ & $\begin{array}{l}0,810 \\
0,802\end{array}$ & $\begin{array}{l}0,350 \\
0,323\end{array}$ & $\begin{array}{l}0,445 \\
0,421\end{array}$ & $\begin{array}{l}0,428 \\
0,404\end{array}$ & $\begin{array}{l}0,619 \\
0,603\end{array}$ \\
\hline F & $\begin{array}{l}100,207^{* * *} \\
(0,000)\end{array}$ & $\begin{array}{l}12,679^{* * *} \\
(0,000)\end{array}$ & $\begin{array}{l}18,825^{* * *} \\
(0,000)\end{array}$ & $\begin{array}{l}17,592^{\text {*** }} \\
(0,000)\end{array}$ & $\begin{array}{l}38,161^{\text {*** }} \\
(0,000)\end{array}$ \\
\hline
\end{tabular}
cient regression $-1<\beta<+1, \varepsilon=$ error term
Table 2 indicates the presence of positive and significative relation between the use of BSC and business performance $(\beta=0,891 ; p=$ $0,000)$ and between each BSC's perspective measures and business performance. These results support $\mathrm{H} 2, \mathrm{H} 2$.a, H2.b, H2.c and H2.d. Business unit size appears not to be significantly associated with performance measures usage.

Table 2: Test of Hypothesis H2; H2.A; H2.B; H2.C and H2.D

\subsection{Market competition- BSC- performance}

To test the direct effect of market competition on performance and the indirect effect of market competition on performance through the use of the $\mathrm{BSC}(\mathrm{H} 3)$, the following regressions was run:

PERFO $=\beta_{0}+\beta_{1}$ CONCU $+\beta_{3}$ SIZE $+\xi$

PERFO $=\beta_{0}+\beta_{1}$ CONCU $+\beta_{2}$ BSC $+\beta_{3}$ SIZE $+\xi$ causal steps approach popularized by Baron and Kenny (1986). The 4 criteria used to define moderators and mediators proposed by the Baron and Kenny has been fulfilled. Table 3 indicates that: 1) the regression coefficient associated with the independent variable CONCU is significant $(\beta=0,425, \mathrm{p}=0,002) ; 2)$ the regression coefficient associated with the mediating variable BSC is significant $(\beta=0,890, \mathrm{p}=0,000) ; 3)$ The overall explanatory power of regression 2 is more important than regression 1 $(0,798>0,184)$ and 4$)$ the regression coefficient associated with the independent variable CONCU is lower in regression $2(0,003$ $<0,425)$. So, the mediating role of the use of the BSC that is discussed earlier is supported (H3 is supported).

Table 3: Test of Hypothesis H3

\begin{tabular}{lll}
\multicolumn{4}{c}{ Table 3: Test of Hypothesis } \\
\hline Variables & $(1)$ & $(2)$ \\
\hline \multirow{2}{*}{ Constant } & $-0,125$ & 0,087 \\
& $(0,476)$ & $(0,651)$ \\
CONCU & $0,425^{* * *}$ & $0,003^{\mathrm{ns}}$ \\
& $(0,002)$ & $(0,963)$ \\
SIZE & $0,138^{\mathrm{ns}}$ & $0,044^{\mathrm{ns}}$ \\
& $(0,295)$ & $(0,507)$ \\
BSC & - & $0,890^{* * *}$ \\
$\mathrm{R}^{2}$ & 0,218 & $(0,000)$ \\
Adjusted $\mathrm{R}^{2}$ & 0,184 & 0,810 \\
$\mathrm{~F}$ & $6,539^{* * *}$ & 0,798 \\
& $(0,003)$ & $65,387^{* * *}$ \\
& $* * * \mathrm{P}<0,01 ; * * \mathrm{p}<0,05 ;{ }^{*} \mathrm{p}<0,1 ;$ ns: no significant.
\end{tabular}

\section{Conclusion}

The objectives of the study was to examine empirically 1) the relationship between the intensity of market competition and managers use of the BSC 2) the relationship between the use of the BSC and Business performance and 3) the mediating role of managers use of the BSC measures in the relationship between the intensity of market competition and business performance.

Data were collected from 50 Tunisian agribusiness units. Results support the three hypotheses. The results reveal that increasing market competition makes greater use of $\mathrm{BSC}$ which improve 
business performance. Results indicate also the presence of an indirect relationship between the intensity of market competition and business performance through the use of the BSC.

However, for the partial hypothesis, results indicate that the intensity of market competition isn't a determinant of the use of the financial perspective of the BSC. In fact, financial measures are used regardless the market context.

In this paper, we attempted to study balanced scorecard and performance in a competitive environment. Our treatment has been necessarily brief and certainly no exhaustive. For instance, we studied the theoretical Kaplan and Norton model; there are other performance measure systems. Then, we studied the agro-food Tunisian firms and ignored others sectors. Future research can extend this study by investigating new strategic performance measure system, other variables (technologies, culture. . .) and other economic sectors.

\section{References}

[1] Abdel-Maksoud, A., Dugdale, D. \& Luther, R. (2005), "Non-financial performance measurement in manufacturing companies", The British Accounting Review, 37, pp. 261-297.

[2] Azofara V, Prieto B \& Santidrian A (2003), the usefulness of a performance measurement system in the daily life of an organisation: a not on a case study. The British Accounting Review, 35, 367-384.

[3] Baron, RM \& Kenny DA (1986), The Moderator-Mediator variable Distinction in Social Psychological Research: Conceptual, Strategic, and Statistical Considerations. Journal of Personality and Social Psychology, 51 (6), 1173-1182.

[4] Bessire D \& Baker CR (2005), The French Tableau de bord and the American Balanced Scorecard: a critical analysis. Critical Perspectives on Accounting, 16, 645-664

[5] Bititici U S, Cavalieri S \& Cieminski G (2005), Implementation of performance measurement systems: private and public sectors. Editorial, Production Planning and Control, 16(2), 99-100.

[6] Braam G J \& Nijssen E J (2004), Performance effects of using the balanced scorecard: a note of the Deutsh experience. Long Range Planning, 37, 335-349.

[7] Bromwich M (1990), the case for strategic management accounting: the role of accounting information for strategy in competitive markets. Accounting, Organizations and Society, 15, 27- 46.

[8] Bryer R (2006), Accounting and control of the labour process. Critical Perspectives on Accounting, 17, 551-598.

[9] Burns J \& Scapens R W (2000), Conceptualizing management accounting change: an institutional framework. Management Accounting Research, 11, 3-25

[10]Cardot C (1998), L'évolution de la comptabilité et ses conséquences sur le contrôle de gestion. Revue Française de Comptabilité, 298, 8892.

[11]Chenhall R H (2005), integrative strategic performance measuremen systems, strategic alignment of manufacturing, learning and strategic outcomes: an explanatory study. Accounting, Organisation and Society, 30, 395-422.

[12]Chenhall R H (2003), Management control systems design within its organisational context: findings from contingency-based research and direction for the future. Accounting, Organisations and Society, 28 $127-168$.

[13]Chenhall R H \& Langfield-Smith K (1998), Factors influencing the role of management accounting in the development of performance measures within organizational change programs. Management Accounting Research, 9, 361- 386.

[14]Chenhall R H \& Langfield-Smith K (1998b), the relation between strategic priorities, management techniques and management accounting: an empirical investigation using a systems approach. Accounting, Organisation and Society, 23 (3), 243-264.

[15]Chong V K \& Rundus M J (2004), Total quality management, market competition and organizational performance, The British Accounting Review, 36, 155-172.

[16]Davis S \& Albright T (2004), an investigation of the effect of Balanced Scorecard implementation on financial performance, Management Accounting Research, 15, 135-153.

[17]Dilla W N \& Steinbart P J (2005), the effects of alternative supplementary display formats on balanced scorecard judgments. International Journal of Accounting Information Systems, 6, 159-176.

[18]Emmanuel C Otley D \& Merchant K, Accounting for Management Control, Second Edition (London: Chapman \& Hall, 1990).
[19]Fullerton R R \& Mc Watters C S (2002), the role of performance measures and incentive systems in relation to the degree of JIT implementation. Accounting, Organisations and Society, 27, 711-735.

[20]Gainey T \& Klaas B S (2003), The Outsourcing of Training and Development: It's Impact on Client Organizations. Journal of Management, 29, 207-229.

[21]Gordon L a \& Narayanan V K (1984), Management accounting systems, perceived environmental uncertainty and organisation structure: an empirical investigation. Accounting, Organisation and Society, 9(1) 33-47.

[22] Hopwood A G (1972), an empirical study of the role of accounting data in performance evaluation. Journal of Accounting Research, 10, $156-182$.

[23] Hoque Z (2003), Total quality management and the balanced scorecard approach: a critical analysis of their potential relationships and directions for research", Critical Perspectives on Accounting, 2003, 14, pp.553-566.

[24] Hoque Z Mia L \& Alam M (2001), Market competition, computeraided manufacturing and use of multiple performance measures: an empirical study. British Accounting Review, 33, 23-45.

[25]Ittner C D, Larcker D F \& Randall T (2003), Performance implications of strategic performance measurement in financial services firms Accounting, Organisations and Society, 28, 715-741.

[26]Joseph N, Turley S, Burns J, Lewis L, Scapens R \& Southworth A (1996), External financial reporting and management information: a survey of U.K Management Accountants. Management Accounting Research, 7, $73-93$.

[27]Kald M \& Nilsson F (2000), Performance Measurement at Nordic Companies. European Management Journal, 18(1), 113-127.

[28]Kaplan R S \& Norton D P (1992), the balanced scorecard-measures that drive performance. Harvard Business Review, Janvier - Février, 71-79.

[29] Kaplan R S \& Norton D P (1992), the balanced scorecard as a strategic management system. Harvard Business Review, Janvier - Février, 61-66.

[30]Kaplan R S \& Norton D P (1996), Using the balanced scorecard as a strategic management system. Harvard Business Review, Janvier Février, 75-85.

[31] Kaplan R S \& Norton D P (2004a), Measuring the strategic readiness of intangible assets. Harvard BusinessReview, 82(2), $52-63$.

[32] Khandwalla P (1972), the effect of different types of competition on the use of management controls. Journal of Accounting Research, 275-285.

[33]Lau C M \& Sholihin M (2005), Financial and non-financial performance measures: How do they affect job satisfaction? The British Accounting Review, 37, 389 - 413

[34]Lipe M G \& Salterio S (2002), a note of judgmental effects of the balanced scorecard's information organisation. Accounting, Organizations and Society, 27, 531-540.

[35] Mahama H (2006), Management control systems, cooperation and performance in strategic supply relationships: A survey in the mines. Management Accounting Research, 17, 315-339.

[36] Martinez V (2005), what is the value of using PMS? Perspectives on Performance, 4 (2), 16-18.

[37]Mia L \& Clarke B (1999), Market competition, management accounting systems and business unit performance. Management Accounting Research, 10, 137-158.

[38] Michalska J (2005), the usage of the Balanced Scorecard for the estimation of the enterprise effectiveness. Journal of Materials Processing Technology, 162-163, 751-758.

[39]Miller P \& O’Leary T (1993), Accounting expertise and the politics of the product: economic citizenship and modes of corporate governance. Accounting, Organizations and Society, 19, 187-206.

[40]Norreklit H (2003), The Balanced Scorecard: What is the score? A rhetorical analysis of the Balanced Scorecard. Accounting, Organisations and Society, 28, 591-619.

[41]Norreklit $\mathrm{H}$ (2000), the balance on the Balanced Score-a critical analysis of some of its assumptions. Accounting, Organisations and Society, $11,65-88$.

[42] Otley D (2001), Management control and performance management: whence and whither? The British Accounting Review, 35, 309-326.

[43] Otley D (2003), extending the boundaries of management accounting research: developing systems for performance management. British Accounting Review, 33, 243-261

[44]Papalexandris an Ionnou G Prastacos G P \& Soderquist K E (2005), an integrated methodology for putting the Balanced Scorecard into action. European Management Journal, 23(2), 214-227.

[45]Robinson R B and Pearce J A (1988), planned patterns of strategic behavior and their relationship to business-unit performance. Strategic Management Journal, 9, 43-60. 
[46]Sohn M H, You T, Lee SL \& Lee H (2003), corporate strategies, environmental forces, and performance measures: a weighting decision support system using the k-nearest neighbour technique. Expert systems with applications, 25, 279-292.

[47]Tuomela TS (2005), the interplay of different levers of control: A case study of introducing a new performance measurement system. Management Accounting Research, 16, 293-320.

[48]Ukko J Tenhunen J \& Rantanen H (2007), Performance measurement impacts on management and leadership: Perspectives of management and employees. Intenrational Journal of Production Economics, doi:10.1016/j.ijpe.2007.02.008

[49]Van Veen-Dirks P \& Wijn M (2002), Strategic control: Meshing critical Success Factors with the Balanced Scorecard. Long Range Planning, 35, 407- 427.

[50]Ward K (1993). Accounting for a 'sustainable competitive advantage. Management Accounting, 71, 36.

[51]Widener S K (2006), Associations between strategic resource importance and performance measure use: the impact on firm performance. Management Accounting Research, 17, 433-457.

[52]Yaich A (2004), La comptabilité financière vit-elle son âge d'or? La Revue Comptable ET Financière, 1er trimestre, No. 63. 